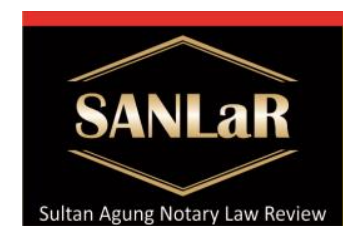

Volume 2 No. 4, December 2020
Sultan Aqung

Notary Law Review

ISSN 2686-4428

published by Sultan Agung

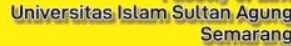

The Responsibilities Of Notaries...(Mega Arum Saputri)

\title{
The Responsibilities of Notaries/Land Deed Making Officials (PPAT) to Electronic Mortgages Based on the Regulation of the Minister of Agrarian
}

\author{
Mega Arum Saputri *), Gunarto **) and Amin Purnawan ***)
}

${ }^{*}$ Student of Master of Notary Law, Faculty of Law, Universitas Islam Sultan Agung (UNISSULA) Semarang, E-mail: megaarumsaputri@gmail.com

$\left.{ }^{* *}\right)$ Lecturer of Master of Notary Law, Faculty of Law, Universitas Islam Sultan Agung (UNISSULA) Semarang

$\left.{ }^{* * *}\right)$ Lecturer of Master of Notary Law, Faculty of Law, Universitas Islam Sultan Agung (UNISSULA) Semarang

Abstract. Notary is a public official who is authorized to make authentic deeds as long as the making of certain authentic deeds is not specific to other public officials. Notary, in this case, is a public official who is given the authority to make authentic deeds regarding certain legal actions regarding land rights or property rights over apartment units, while PPAT deeds are deeds made by PPAT as evidence that certain legal actions have been carried out regarding land rights or ownership rights over flat units, PPAT deed is a tool to prove that a legal act has been committed. The problems in this thesis are: (1) What is the responsibility of a PPAT Notary for electronic mortgage certificates based on the Minister of Agrarian Regulation Number 9 of 2019 ?, (2) What are PPAT Notary Obstacles in storing electronic mortgage documents? The Land Office regarding electronic mortgage certificates based on the Minister of Agrarian Regulation Number 9 of 2019? The method used is juridical empirical, with descriptive analytical specifications of data collected with primary data from field research and secondary data from literature studies, while qualitative data. The results of this study are: (1) The responsibility of the Notary/PPAT for electronic mortgage documents based on the Minister of Agrarian Regulation Number 9 of 2019 is to assist the government's duties. HT-el service is a form of service provision from the Ministry of ATR/BPN in facilitating services to the community by taking advantage of developments in information technology. PPAT is exempted from the obligation to represent the applicant (creditor) but PPAT is still obliged to submit the deed it has made, including APHT as quickly as possible and no later than 7 days. (2) Obstacles to the Notary/PPAT in storing electronic mortgage documents include a) constraints from the Creditor (Bank), where in each Notary-PPAT credit binding process b) Constraints from the Debtor (Client). c) Constraints from BPN, which is for clients who want all the management processes such as checking, registration, roya and so on related to the installation of Mortgage Rights at the BPN office can use an accelerated process even though they have to pay more than the specified administrative fee. (3) Efforts by the Notary/PPAT and the Land Office to electronic mortgage certificates based on the Regulation of the Minister of Agrarian Affairs Number 9 of 2019 are that PPAT Notaries need to apply the principle of prudence in examining HT-el certificates submitted by the tappers. The suggestion in this research is that the Notary 
Public/PPAT needs to make readiness in the procurement of electronics and technology that is qualified in HT-el registration and needs to apply the principle of prudence.

Keywords: Notary-PPAT; Letter; Electronic Mortgage.

\section{Introduction}

Economic development, as part of national development, is one of the efforts to create a just and prosperous people's welfare based on Pancasila and the 1945 Constitution. In order to maintain the continuity of development, the actors include both the government and the community as individuals and bodies. law, it is necessary to fund large amounts. With the increase in development activities, the need for availability of funds also increased, most of which was obtained through credit activities.

Banking credit is one of the conventional bank businesses that have been widely used by people who need funds in Article 1 point 2 of Act No. 10 of 1998 Concerning Banking, Banks are business entities that collect funds from the public in the form of deposits and channel them to the public in the form of credit and or other forms in order to improve the standard of living of the people at large, banks also function as financial intermediaries aimed at supporting development. national not individual development, increasing the distribution of people's welfare at large, not the welfare of individuals or groups and increasing economic growth and national stability. ${ }^{1}$ Credit agreements are usually made by the credit provider, namely the bank, while the debtor only studies it and understands it. However, this credit agreement should really need special attention from both parties because the credit agreement has a very important function in providing, managing and implementing it because there is an agreement between the two parties that we can call a debtor and creditor, because if the debtor signs a credit agreement that is considered binding on both parties and applies as a law for both. ${ }^{2}$

Given the importance of the position of credit funds in the development process, it is appropriate that creditors and recipients of credit and other related parties receive protection through a strong guarantee rights institution that can also provide legal certainty for all interested parties. ${ }^{3}$ One of the strong guarantee institutions that can be charged with land rights that will be discussed in this paper is the mortgage right. Security rights are security rights over land for the settlement of certain debts, which give priority to certain creditors over other creditors. ${ }^{4}$ This means that if the debtor defaults, the creditor holding the mortgage has the right to sell through a public

\footnotetext{
${ }^{1}$ Harahap, M. Yahya. (1997). Beberapa Tinjauan Tentang Permasalahan Hukum Buku Kedua. Bandung: Citra Aditya Bakti. p. 210

2 Sjahdeini, Sutan Remy. (1999). Hak Tanggungan Asas-Asas Ketentuan-Ketentuan Pokok dan Masalah Yang Dihadapi Oleh Perbankan (Suatu Kajian Mengenai Undang-Undang Hak Tanggungan). Bandung: Alumni. p. 26

3 Sutedi, Adrian. (2006). Implikasi Hak Tanggungan Terhadap Pemberian Kredit Oleh Bank dan Penyelesaian Kredit Bermasalah. Jakarta: BP Cipta Jaya. p. 1

${ }^{4}$ HS, Salim. (2014). Perkembangan Hukum Jaminan di Indonesia. Jakarta: PT Raja Grafindo.
} 
auction of land which is used as collateral according to the provisions of the relevant laws and regulations, with pre-emptive rights over other creditors. ${ }^{5}$

According to Article 1 paragraph 1 of Act Number 4 of 1996 concerning Mortgage Rights to Land and Objects Related to Land (hereinafter referred to as "UUHT"), Land Mortgage Rights and objects related to land are guaranteed rights charged to the land rights as referred to in Act Number 5 of 1960 concerning Basic Agrarian Principles (hereinafter referred to as "LoGA"), the following or not including other objects constitute an integral part of the land, for the settlement of certain debts, which give a position that is give priority to certain creditors over other creditors. ${ }^{6}$

The definition of Mortgage above is not limited to the focus on land alone, but also on other objects that are related or become an integral part of the land. This is different from the provisions in the UUPA, which adhere to the principle of horizontal separation, namely the separation between land and buildings above it $^{7}$ According to Article 4 of the UUHT, the objects of the Mortgage Rights are property rights, land use rights, building use rights and usage rights over State land, which according to the applicable provisions must be registered and according to their nature can be transferred. ${ }^{8}$ Granting of mortgage rights is carried out by making a Deed of Granting Mortgage Rights (hereinafter referred to as "APHT") which is made by the Official for Making Land Deeds (hereinafter referred to as "PPAT") in accordance with the prevailing laws and regulations. ${ }^{9}$ This Mortgage has the nature of accesoir or a followup agreement, which means that the debt guarantee agreement for the security right does not stand alone because it was preceded by a principal agreement, namely a debt agreement. If the principal agreement is canceled or canceled, then the accesoir agreement is automatically canceled. ${ }^{10}$

Notary, in this case, is a public official who is given the authority to make authentic deeds regarding certain legal actions regarding, land rights or property rights over apartment units, while PPAT deeds are deeds made by PPAT as evidence that certain legal actions have been carried out regarding land rights or ownership rights over apartment units, PPAT deed is a tool to prove that a legal act has been committed. ${ }^{11}$ Therefore, if the legal act is canceled or canceled, the PPAT deed concerned will no longer function as evidence of said legal act. PPAT is appointed and

\footnotetext{
${ }^{5}$ Ibid, p. 3

6 S. Suriasumantri, Jujun. (2007). Filsafat IImu Sebuah Pengantar Populer. Jakarta: Pusataka Sinar Harapan.

7 Harsono, Boedi. (1999). Hukum Agraria Indonesia Sejarah Pembentukan Undang-Undang Pokok Agraria, Isi dan Pelaksanaannya. Cetakan ke-8. Jakarta: Djambatan. p. 19.

8 Lili Rasjidi, Ira Thania Rasjidi. (2002). Pengantar Filsafat Hukum. Mandar Maju. Bandung: Thafa Merdeka

9 Bahsan, M. (2010). Hukum Jaminan dan Jaminan kredit Perbankan Indonesia. Jakarta: PT. Raja Grafindo Persada.

${ }^{10}$ Samekto, Fx Adji. (2013). Hukum Dalam Lintasan Sejarah. Semarang: Indepth Publishing.

${ }^{11}$ Soedjendro, Kartini. (2001). Perjanjian Peralihan Hak atas Tanah yang Berpotensi Konflik. Yogyakarta: Kanisius
} 
dismissed by the Minister of Agrarian Affairs to serve the community in making PPAT deeds in certain areas. ${ }^{12}$

In the credit agreement made referring to the UUHT, it must be stated in the authentic deed made by PPAT. ${ }^{13}$ As for several agreements signed, among others: credit agreement, debt acknowledgment, Deed of Assignment of Mortgage Rights (APHT). Deed of Assignment of Mortgage Rights (hereinafter referred to as APHT) drawn up before the Authorized Land Deed Maker (PPAT) in accordance with the PPAT working area, based on the elements and procedures for making APHT, the APHT is an authentic deed. ${ }^{14}$

As an authentic deed, in addition to fulfilling the elements of an authentic deed determined by the Civil Code and the Law on Notary Position, APHT has characteristics and must meet the requirements as specified in the Mortgage Rights Law. The process of imposition of mortgage rights based on the Mortgage Rights Law is through two stages, first, the stage of granting Mortgage Rights by making a Deed of Granting Mortgage Rights (APHT) by PPAT, previously a debt agreement has been made which is the basis of this Mortgage Rights second, the registration stage by the Land office, this registration is important because it proves the birth of the insurance rights that are charged, after the APHT is made by the parties concerned, ${ }^{15}$ National Land Agency National Land Agency (BPN) is a state administrative institution whose authority only carries out tasks in the field of government, ${ }^{16}$ but recently the Minister of ATR/Head of BPN issued Regulation of the Minister of Agrarian Affairs and Spatial Planning for the Head of the National Land Agency Number 9 of 2019 concerning Electronically Integrated Mortgage Services which came into effect since it was promulgated, namely from 21 June 2019 (Permen ATR/KBPN 9 of 2019 ). This Permen is a continuation of the previous ATR/KBPN Permen, namely Permen No. 3 of 2019 concerning the use of electronic systems and Permen No. 7 of 2019 concerning changes in the form of certificates.

The issuance of these candies is a rare step forward by the Ministry of Agrarian Affairs and Spatial Planning of the National Land Agency in making it easier for the public to get services from the ministry by utilizing the Ministry of Agriculture technological ideas, although the Ministerial Regulation has been issued and is in effect since it was promulgated, the implementation of Permen No. 9 of 2019 regarding HT-el still depends on the readiness of each land office in implementing an electronic system in providing services to the community. ${ }^{17}$

\footnotetext{
12 Hermansyah. (2005). Hukum Perbankan Nasional Indonesia. Jakarta: Prenada Media. p. 20

${ }^{13}$ HS, Salim. (2015). Teknik Pembuatan Akta Satu. Jakarta: PT. Raja Grafindo Persada

${ }^{14}$ Habib, Adjie. (2007). Hukum Notaris Indonesia, Tafsir Tematik Terhadap Undang-Undang Nomor 30 Tahun 2004 tentang Notaris. Surabaya: Refika Aditama

15 Kusumaatmadja, Mochtar. (2003). Hukum, Masyarakat dan Pembinaan Hukum Nasional. Jakarta: Binacipta.

${ }^{16}$ Sutedi, Adrian. (2012). Hukum Hak Tanggungan. Jakarta: Sinar Grafika. p. 161.

17 HS, H. Salim. (2017). Perkembangan Hukum Jaminan di Indonesia. Jakarta: Raja Grafindo Persada
} 
There are important points in HT-el related to the duties, functions and authorities of PPAT; there is a separation between the act of registering HT-el with the act of submitting the APHT deed to the Land Office. If all this time the act of submitting deeds as well as registration of Mortgage Rights is assigned to PPAT then in the Ministerial Regulation separating it into submission of APHT to the Land Office remains the task of PPAT to deliver the deed it has made within the specified time limit, submission of the deed can be done electronically (Article 10 ) and the application for HT-el registration is the obligation of the creditor, so that if the creditor is negligent in not registering it, the risk and legal consequences will result in the guarantee given not giving the special rights granted by the Mortgage Law.

Based on the background description of the problem above, writing can formulate legal issues related to research, as follows:

a. What is the responsibility of the Notary/PPAT towards electronic mortgage certificates based on the Minister of Agrarian Regulation Number 9 of 2019?

b. What are the Constraints for the Notary/PPAT in storing electronic mortgage documents?

c. How are the efforts of the Notary/PPAT and the Land Office towards electronic mortgage certificates based on the Minister of Agrarian Regulation Number 9 of 2019?

\section{Research Methods}

The method used in this research is empirical juridical method. Research using the empirical juridical method is research on the effect of the law on society. This study uses primary data sources and secondary data sources. Primary data sources are sources obtained from field research, while secondary data sources consist of primary legal materials, secondary legal materials, and tertiary materials. Then the data were analyzed qualitatively.

In conducting data analysis, a qualitative analysis method is used, which is a research method that produces descriptive analysis data. Analysis descriptive data is data that is collected without using numbers and measurements, so that what the respondent states in writing or orally and what is researched and studied is something that is intact.

\section{Results and Discussion}

\subsection{The Responsibility of Notary Public/PPAT towards Electronic Mortgage Certificates} Based on the Minister of Agrarian Regulation Number 9 of 2019

Banks are business entities that carry out activities to collect funds from the public in the form of savings and channel them back to the community in the form of loans or in other forms in an effort to improve people's lives, from the meaning described in Article 1 Paragraph 2 of Act No. 10 Years 1998 Concerning Banking, it can be concluded 
that banking business activities include: $\left.{ }^{18} 1\right)$ Raising Funds; 2) Channeling Funds; 3) Providing other Bank Services.

In the process of granting credit, banks must adhere to the principle of prudence and must be based on economic principles in accordance with Article 2 of Act No.10 of 1998 concerning Banking. Furthermore, the application of the precautionary principle referred to in Article 2 is regulated in Article 8 paragraph 1 of Act No.10 of 1998 concerning Banking, that the precautionary principle is applied through an analysis process on the part of the Bank and based on the good faith of the Debtor that the debtor has willingness and ability to pay the loan in accordance with the agreement. ${ }^{19}$

Pursuant to Article 8 paragraph 2 of Act No.10 of 1998 concerning Banking that Commercial Banks in implementing credit activities must be based on the provisions stipulated by Bank Indonesia, while Article 29 Paragraph 3 of Act No.10 of 1998 concerning Banking states that banks are required to comply with the methods that is not detrimental to the interests of customers who have entrusted their funds in carrying out their business activities to provide credit or financing and carry out other business activities.

The implementation of the provision of bank credit by taking into account related legal aspects including the legal aspects of guarantee. In the Guarantee Law in effect in Indonesia, that guarantee can be classified into 2 (two), namely Material Guarantee and Personal Guarantee. Material guarantees are the rights of creditors to get priority to obtain repayment of their receivables prior to other creditors. Meanwhile, individual security is an individual guarantee personally for certain debts from a debtor. $^{20}$

Regarding special matters related to collateral in the form of land, since 1996 there has been a legal unification in the Guarantee Law for land, namely with the issuance of Act Number 4 of 1996 concerning Land Mortgage Rights and Objects related to Land, hereinafter abbreviated as UUHT. The birth of the UUHT is a mandate of Article 51 of Act Number 5 of 1960 concerning Basic Agrarian Principles, which states "Mortgage rights that can be imposed on Property Rights, Business Use Rights, and Building Use Rights in Articles 25, 33 and 39 are regulated by law".

Prior to 1996 the land guarantee institution in effect was Mortgages whose material provisions were regulated in Book II of the Civil Code (as long as the land, water and wealth in it had been revoked by the UUPA) and the granting of registration was regulated in Staatblads. 1908-542 as amended by Staatblad. 1937-190 juncto Staablads. 1937-191. ${ }^{21}$ With the enactment of Act Number 4 of 1996 concerning Mortgage Rights on Land and objects related to land, based on Article 29 of the Law, the Mortgage and Credietverband guarantee institutions are declared invalid, further stipulated that the Mortgage Rights as a guarantee institution land rights. The

\footnotetext{
${ }^{18}$ Cashmere. (2012). Manajemen Perbankan. Jakarta: Raja Grafindo Persada. p. 13.

19 Untung, H. Budi. (2012). Visi Global Notaris. Yogyakarta: Andi

${ }^{20}$ Bahsan, M. (2007). Hukum Jaminan dan Jaminan Kredit. Jakarta: Raja Grafindo Persada. p. 70

${ }^{21}$ HS, Salim. (2007). Perkembangan Hukum Jaminan di Indonesia. Jakarta: Raja Grafindo Persada
} 
definition of Mortgage is the collateral right imposed on land rights as referred to in the Mortgage Rights Law, including or not following other objects which are an integral part of the land, for the settlement of certain debts which give priority to certain creditors to creditors. other. ${ }^{22}$

The elements contained in the definition of Mortgage are as follows:

1. Security rights imposed on land rights; what is meant by security rights over land is a control right that can specifically be granted to a creditor, which authorizes him to, if the debtor fails to promise, sell a land auction which is specifically designated as collateral for his receivables and take all or part of it. the result is for the settlement of the debt, with prior rights over other creditors (droit de preference).

2. Right to the following land or not including objects that are an integral part of the land;

3. To pay off certain debts;

4. Giving priority to certain creditors over other creditors (droit de preference). ${ }^{23}$

As referred to in Article 51 of Act Number 5 of 1960 concerning Basic Agrarian Regulations. As for the object of the Mortgage in Article 4 paragraph (1) and paragraph (2) of the UUHT, it is stated that: "Land rights that can be encumbered with the Mortgage Rights are Property Rights, Business Use Rights and Building Use Rights."

In addition to the rights to land as mentioned above, Article 4 paragraph (2) of the UUHT also regulates that it is also possible that the Right to Use over State Land which according to the applicable provisions must be registered and according to its transferable nature can also be encumbered with Mortgage Rights. In order to be encumbered with a Mortgage, the object of the Mortgage Rights on the land concerned must meet 4 requirements, namely:

1. Can be valued in money;

2. Including Rights listed in the public register;

3. Has transferability;

4. Requires appointment by law. ${ }^{24}$

As Article 4 paragraph (1) of the UUHT reads, one of the objects of Mortgage Rights is Building Use Rights. Hak Guna Bangunan is the right to build and own buildings on land that is not his own, with a maximum period of 30 years. Furthermore, at the request of the right holder and taking into account the needs and condition of the buildings, the 30 year period may be extended for a maximum period of 20 years. Building Use Rights

\footnotetext{
22 Soejono, Abdurrahman. (1998). Prosedur Pendaftaran Tanah Hak Milik, Hak Sewa Bangunan, Hak Guna Bangunan. Jakarta: Rineka Cipta.

${ }^{23}$ HS, Salim. (2005). Perkembangan Hukum Jaminan dilndonesia. Jakarta: Rajawali Pers. p. 96

24 Patrik, Purwahid and Kashadi. (2008). Hukum Jaminan. Edisi Revisi dengan UUHT. Semarang : Fakultas Hukum (Universitas Diponegoro Semarang. p. 13
} 
can be transferred and transferred to other parties. Land rights that can be encumbered with a Mortgage Rights according to Article 4 of the UUHT, namely Property Rights, Business Use Rights, Building Use Rights (Articles 25, 33 and 39 of Government Regulation Number 40 of 1996), Use Rights of State Land which according to the applicable provisions must be registered and according to their nature transferable, ${ }^{25}$

Building use rights can be used as collateral for debt, namely by being burdened with Mortgage Rights. In the process of converting to Hak Milik, Hak Guna Bangunan the legal result is the abolition of the Building Use Rights over land that was originally state land, before being granted new land rights, namely Hak Milik. In the event that the Building Use Rights have been used as collateral for a certain debt and are encumbered with a mortgage while its validity period is nearing its end, usually the owner prefers to upgrade it to Hak Milik status rather than extend the term of Hak Guna Bangunan, because the cost of increasing the Building Use Rights to Rights Ownership is cheaper than the extension of the Building Use Rights. ${ }^{26}$

Public officials who are authorized to make deeds of transfer of land rights and other deeds in the framework of the imposition of rights to land, the form of the deeds are stipulated as evidence of certain legal acts concerning land located in their respective working areas, as referred to above is the Land Deed Making Official (PPAT). The position of the PPAT as mentioned above means that the deeds made by the PPAT are authentic deeds. The imposition of land rights under PPAT's authority, one of which is the making of the Deed of Granting Mortgage Rights (APHT) which will be used as a discussion in the case study in this paper.

In granting mortgage rights, the guarantor of the mortgage must be present before the PPAT, if the person concerned is unable to attend, then he is obliged to appoint another person as a proxy by means of a Power of Attorney to Impose Mortgage Rights (hereinafter also referred to as "SKMHT") which can be made by a Notary, or can also made by PPAT whose authority extends to the sub-district area. At the time of making the SKMHT and APHT, the Notary/PPAT concerned must be sure that the guarantor of the mortgage right has the authority to take legal action against the object of the mortgage that is charged, even though certainty regarding the possession of this authority is only required when the mortgage right is registered.

The importance of making APHT by PPAT is as a basis for guarantee for creditors, namely by imposing mortgage rights on the object of guarantee. This is of course to protect the interests of the parties (both creditors and creditors) and as legal certainty for these parties, as the holder of preference rights. In carrying out their duties and responsibilities, the Officials for Making Land Deeds (PPAT) have received legal certainty since the promulgation of Regulation of the Head of the National Land

25 Harsono, Boedi. (2007). Hukum Agraria Indonesia, Himpunan Peraturan-Peraturan HukumTanah. Jakarta: Djambat. p. 42

${ }^{26}$ Sudrajat, Sutardja. (1997). Pendaftaran Hak Tanggungan dan Penerbit Sertifikatnya, Bandung: Mandar Maju. 
Agency Number 1 of 2006 concerning Provisions for Implementing Government Regulation Number 37 of 1998 concerning the Position Regulations for Land Deed Making Officials ("KBPN Regulation No. 1 of 2006 ") on May 16, 2006, namely in the form of guidelines for making land deeds as regulated in Article 54, which reads:

1. Prior to drawing up a deed regarding legal action as referred to in Article 2 letter a to letter $\mathrm{g}$, the PPAT is obliged to carry out an examination of the suitability or validity of the certificate and other records at the local Land Office by explaining its aims and objectives;

2. In making deeds as referred to in paragraph (1), PPAT is not allowed to contain the words "according to or according to the statements of the parties" unless it is supported by formal data;

3. PPAT has the authority to refuse the making of deeds, which are not based on formal data;

4. PPAT is not allowed to make deeds as referred to in Article 2 letter a to letter $\mathrm{g}$, for part of land parcels that have been registered or customary land, before being measured by the Land Office and given a Land Parcel Identification Number (hereinafter also referred to as "NIB"), and ;

5. In making deeds, PPAT is obliged to include the NIB or land title number, Land and Building Tax (PBB) Payable Tax Return (SPPT) number, land use and utilization in accordance with field conditions. Thus, the KBPN Regulation No. 1 of 2006 can be a clear reference for PPAT in making deeds within the scope of land, especially APHT, so as to avoid mistakes that can cause harm to the parties involved in the deed.

With regard to the provision of guarantees in the lending and borrowing agreement between the debtor and creditor in relation to fixed objects in the form of land, it is carried out by installing Mortgage Rights (HT). In the era of accelerated electronic technology, the Minister of ATR/Head of BPN issued a Regulation of the Minister of Agrarian Affairs and Spatial Planning for the Head of the National Land Agency Number 9 of 2019 concerning Electronically Integrated Mortgage Services which came into effect since it was promulgated on 21 June 2019 (Permen ATR/KBPN 9/2019) ). Regulation of the Minister of Agrarian and Spatial Planning/Head of the National Land Agency of the Republic of Indonesia number 9 of 2019 concerning integrated electronic insurance services, hereinafter referred to as the HT-el system, is a series of mortgage service processes in the context of maintaining land registration data which is carried out through an integrated electronic system. Types of mortgage services that can be requested through the electronic mortgage system are: ${ }^{27}$

1. Registration of mortgage rights;

2. Transfer of mortgage rights;

3. Change of debtor name;

4. Abolition of mortgage rights;

This provision was issued because it considers the improvement of services, timeliness, speed, convenience and affordability in the framework of public services, as well as to adjust legal developments, technology and community needs, it is necessary to take

${ }^{27}$ Interview with Sugeng Budiman, as Notary-PPAT Semarang City, on April 23, 2020 
advantage of information technology so that procedures for insurance services can be integrated electronically so that it becomes more effective and efficient. The provisions regarding Mortgage Rights have previously been regulated in UUHT Number 4 of 1996 concerning Mortgage Rights for Land and other objects related to Land. ${ }^{28}$

Mortgage rights in the National Security Law referred to by the UUPA, were previously unknown, both in the Customary Law and in the Civil Code. However, it is then regulated in Article 51 of the UUPA that it is stipulated that Mortgage Rights can be imposed on Ownership Rights, Business Use Rights and Building Use Rights as regulated by law. Based on the mandate of Article 51 of the UUPA, Act Number 4 of 1996 concerning Land Mortgage Rights and Land-Related Objects (UUHT) was promulgated. In Article 29 of the UUHT it is determined that with the enactment of the UUHT, the provisions regarding Credietverband and the provisions regarding Hypotheek as mentioned in Book II of the Civil Code as long as the imposition of Mortgage Rights on land rights and objects related to land are declared invalid.

Article 13 paragraph (1) UUHT requires APHT to be registered at the Land Office. Registration of registration is carried out by the Land Office. However, the UUHT did not regulate who was the applicant for the HT registration. In PP 24/1997, those who can request land registration are land owners or rights recipients. Likewise in the case of mortgage rights, the applicant for registration is the recipient of the mortgage, namely creditors.

So far, registration has been done manually by submitting physical evidence at the counter at the land office, with PPAT first registering the registration online on the official portal of the Ministry of ATR/BPN. Application for registration and submission of APHT shall be carried out simultaneously by PPAT or an authorized person. Article 3 paragraph (2) Permen No. 9/2019 which regulates that services of mortgage rights can be carried out electronically through the HT-el System. The phrase "can" implies that there are options in obtaining mortgage services, namely manually as before, or through the HT-e system.

The supporting documents or those that will later be used as evidence According to Law 11 of 2008 concerning Electronic Information and Transactions Article 1 Paragraph 6 and 7, it is written that the meaning of the two electronic evidence is:

"Electronic information is one or a set of electronic data, including but not limited to writing, voice, images, maps, designs, photos, electronic data interchange (EDI), electronic mail (electronic mail), telegram, telex, telecopy or the like, letters Processed signs, numbers, access codes, symbols, or perforations that have meaning or can be understood by those who are able to understand them. "

\footnotetext{
28 Kedudukan dan Kepastian Hukum Hak Tanggungan Elektronik, https://notarymagazine.com/kedudukan-dan-kepastian-hukum-ht-elektronik/, accessed on 23 April 2020
} 
Electronic Document is any Electronic Information created, forwarded, sent, received, or stored in analog, digital, electromagnetic, optical, or the like, which can be seen, displayed, and/or heard through computers or Electronic Systems, including but not limited to in writing, voice, pictures, maps, designs, photographs or the like, letters, signs, numbers, access codes, symbols or perforations which have meaning or meaning or can be understood by those who are able to understand them.

Permen 9/2019 also regulates special matters, including in Article 7, namely HT-el users are creditors, Article 9 paragraph (5) the HT provider must be the debtor himself. Thus, if the HT provider is not a debtor, he/she cannot use the HT-el service, which means that HT registration is done manually/physically. The provisions of Article 9 paragraph (5) are not prohibited from granting HT by other parties (collateral owners) who are not debtors. This provision seems easy but there is no regulation on how there is another party or a third party as a guarantor. Because in the business world a trust system develops between the parties. The regulation also separates the prevailing customs, namely the act of applying for APHT registration from the submission of APHT by PPAT. The submission of the APHT is an obligation of the PPAT under the threat of sanctions if it is negligent. Meanwhile, the application for HT registration services acts as an attorney acting on behalf of HT recipients or creditors. HT PPAT HT-el registration services that carry out the registration process, are only alternative and not mandatory. If after the implementation of HT-el then manual HT services are not organized or eliminated by the Land Office, then it means that the Land Office which refuses to register HT-el outside HT-el is contrary to Permen 9/2019 and UUHT.

In the event that HT-el registration services outside the HT-el system are abolished, where HT-el only registers HT from the debtor's HT Giver (vide Article 9 paragraph (5), it can be interpreted that Article 9 paragraph (5) Permen 9/2019 as a form prohibition for HT that does not belong to the debtor and it contradicts the UUPA and UUHT.There are provisions of the Ministerial Regulation on electronic HT registration that are contrary to the UUHT.

Since the issuance of Regulation of the Minister of Agrarian Affairs and Spatial Planning/Head of the National Defense Agency Number 9 of 2019 concerning Electronically Integrated Mortgage Services ("Agrarian Regulation 9/2019"), the term Electronic Mortgage System ("HT-el System") is known. The HT-el system, as referred to in Article 1 point 6 of the Agrarian Ministerial Regulation 9/2019, is a series of mortgage service processes in the context of maintaining land registration data which is carried out through an integrated electronic system.

The implementation of the HT-el system is carried out by the Land Office in stages according to the readiness of supporting data. ${ }^{29}$ One of the types of mortgage services that can be submitted through the HT-e system is registration of mortgage rights as

\footnotetext{
29 Mekanisme Pendaftaran Hak Tanggungan Secara Elektronik, https://www.hukumonline.com/klinik/detail/ulasan/lt5d78bcd61c63c/mekanisme-pendaftaran-haktanggungan-secara-elektronik/, accessed on 23 April 2020
} 
you ask. In addition, this system also serves transfer of Mortgage Rights, change of creditor names and abolition of Mortgage Rights. ${ }^{30}$

Basically, according to Article 7 Permen 9/2019 concerning Integrated Mortgage Services Electronically to use the HT-e System, users must be registered first with the following conditions:

1. Users of HT-e system services consist of individuals/legal entities as creditors and the Ministry's State Civil Apparatus in charge of serving Mortgage Rights;

2. Individuals/legal entities as intended previously must be registered users of the HT-el System, by meeting the following requirements:

a. has an electronic domicile;

b. Certificate of Registered at the Financial Services Authority;

c. statement of fulfillment of the requirements and criteria as well as approval of the provisions as a Registered User; and

d. other requirements determined by the Ministry.

3. The Ministry verifies the registration and has the right to refuse the said registration. With regard to the provision of guarantees in the lending and borrowing agreement between the debtor and creditor in relation to fixed objects in the form of land, it is carried out by installing Mortgage Rights (HT). In the era of accelerated electronic technology, the Minister of ATR/Head of BPN issued Regulation of the Minister of Agrarian Affairs and Spatial Planning for the Head of the National Land Agency Number 9 of 2019 concerning Electronically Integrated Mortgage Services which came into effect since it was promulgated on 21 June 2019 (Permen ATR/KBPN 9/2019) ).

This provision was issued because it considers the improvement of services, timeliness, speed, convenience and affordability in the framework of public services, as well as to adjust legal developments, technology and community needs, it is necessary to take advantage of information technology so that procedures for insurance services can be integrated electronically so that it becomes more effective and efficient. The provisions regarding Mortgage Rights have previously been regulated in UUHT number 4 of 1996 concerning Mortgage Rights for Land and other objects related to Land. ${ }^{31}$

Mortgage rights in the National Security Law referred to by the UUPA, were previously unknown, both in Customary Law and in the Civil Code. However, it is then regulated in Article 51 of the UUPA that it is stipulated that Mortgage Rights can be imposed on Ownership Rights, Business Use Rights and Building Use Rights as regulated by law. Based on the mandate of Article 51 of the UUPA, Act Number 4 of 1996 concerning Land Mortgage Rights and Land-Related Objects (UUHT) was promulgated. In Article 29 of the UUHT it is determined that with the enactment of the UUHT, the provisions regarding Credietverband and the provisions regarding Hypotheek as mentioned in Book II of the Civil Code as long as the imposition of Mortgage Rights on land rights and objects related to land are declared invalid.

\footnotetext{
$30 \mathrm{Ibid}$

${ }^{31}$ Thamrin, Husni. (2010). Pembuatan Akta Pertanahan oleh Notaris. Yogyakarta: LaksBang Pressindo.
} 
Based on Permen No. 3/2019 concerning electronic signatures and Permen No. 7/2019 regarding the form of SHAT, it seems that the Ministry of ATR/BPN is preparing to use information technology in providing land services for the community. From an examination of various regulations related to Mortgage Rights, it can be concluded that;

PPAT is a general official who has the function of helping government tasks (in this case the Ministry of ATR/BPN). Those in charge of ratifying certain legal acts whose object is land. Thus the main task of the PPAT is to make deeds and submit deeds made to the Land Office for registration of data maintenance.

Furthermore, the electronic HT service is a form of service provision from the Ministry of ATR/BPN in order to facilitate services to the public by taking advantage of developments in information technology. Electronic $H T$ is an option for registering mortgage rights so that people can register $\mathrm{HT}$ either manually or through the electronic HT system. In this candy HT electronic service users are HT and ASN recipient creditors who are assigned to HT services. Meanwhile, PPAT in this case is exempted from the obligation to represent the applicant (creditor) but is obliged to submit the deed it has made, including APHT, within 7 days as soon as possible. However, it turns out that PPAT is not given access to electronic HT,

In general, the four conditions explain that the agreement must be based on the will of all parties. Then, the second condition means that the contracting party must have subjective authority over the law. Meanwhile, the third and fourth conditions are objective. How can PPAT as the party who took part in the process of submitting to registration of E-documents to the parties concerned here, namely as the land office is not given the authority to access the applicant's personal data. And it is clear here that it deviates from the principle of information disclosure considering that PPAT is the party involved in it, PPAT also has the right to check the mortgage certificate process. Then where is the role of the PPAT as the official in charge of processing land objects that the applicants want to install the Mortgage Rights as the party that previously assisted the applicant's registration process and then registered with the BPN, if you look back, it seems there is a complete delegation of authority to the Land Office in the registration process, whether The procedure for fulfilling physical data and Edocuments without exception E-Sign and E-Fingerprint is carried out by the applicant to the land office or there is elaboration between the PPAT and the land office in the process of transferring rights and registration. Because in Permen No. 9 of 2019 it is not clearly regulated who the party must process regarding the transfer or registration of the Mortgage itself. whether the procedure for fulfilling physical data and Edocuments without exception E-Sign and E-Fingerprint is carried out by the applicant to the land office or is there an elaboration between the PPAT and the land office in the process of transferring rights and registration. Because in Permen No. 9 of 2019 it is not clearly regulated who the party must process regarding the transfer or registration of the Mortgage itself. whether the procedure for fulfilling physical data and E-documents without exception E-Sign and E-Fingerprint is carried out by the applicant to the land office or is there an elaboration between the PPAT and the land 
office in the process of transferring rights and registration. Because in Permen No. 9 of 2019 it is not clearly regulated who the party must process regarding the transfer or registration of the Mortgage itself. ${ }^{32}$

\subsection{Obstacles to the Notary/PPAT in storing electronic mortgage documents}

Notary is a public official who is authorized to make authentic deeds as long as the making of certain authentic deeds is not specific to other public officials. ${ }^{33}$ The making of authentic deeds is required by laws and regulations in order to create legal certainty, order and protection. In addition to authentic deeds made by or before a Notary, not only because they are required by laws and regulations, but also because interested parties want them to ensure the rights and obligations of the parties for certainty, order and legal protection for the parties concerned at once, for society as a whole.

No different from a notary, PPAT also has an important role in implementing land administration data on land registration. According to Government Regulation Number 24 of 1997 concerning Land Registration, transfer and imposition of land rights can only be registered if proven by a PPAT Deed. PPAT is a public official who is given the authority to make authentic deeds regarding certain legal actions regarding land rights or property rights over apartment units.

PPAT has the main task of carrying out some land registration activities by making deeds as evidence of certain legal actions regarding land rights or property rights over apartment units, which will be used as the basis for registering changes to land registration data as a result of this legal act. ${ }^{34}$

Article 2 PP No. 37 of 1998, the main tasks of the PPAT are as follows:

a. The PPAT has the main task of carrying out some land registration activities by making deeds as evidence of certain legal actions regarding land rights or property rights over apartment units, which will be used as the basis for registering changes to land registration data as a result of this legal act.

b. (2) The legal actions referred to in paragraph (1) are as follows:

a. buy and sell;

b. exchange;

c. grant;

d. income in the company (inbreng);

e. sharing of joint assets;

f. granting Right to Build/Use Rights over Freehold land;

g. giving Mortgage Rights

h. granting power of attorney to impose Mortgage Rights.

The role of a notary in the credit distribution system carried out by banks is to provide legal certainty for the parties who enter into a credit agreement.In addition, the role of

\footnotetext{
32 Nurita, Emma. (2012). Cyber Notary. Bandung: PT. Rafika Aditama

33 R. Soegondo, Notodisoerjo. (1993). Hukum Notariat Di Idonesia Suatu Penjelasan. Jakarta: Raja Grafindo Persada. p. 14

34 Ibid. p. 16
} 
the PPAT Notary is also the authorized party to check collateral in the form of Mortgage Rights to ensure whether the collateral is valid. in the eyes of the law or not or to avoid if there is a possibility that the collateral that is used as a guarantee is still a legal dispute or legal case. The legalized agreement deed or warmerking and checked by a notary is something that is done to reduce negative factors, for example that the achievements given are in the form of money, goods, ${ }^{35}$

The role of the PPAT Notary is important because this PPAT Notary will provide a written statement regarding whether the collateral to be used as a Mortgage is legal or not, besides that the PPAT Notary in this credit agreement must also make a Deed of Granting Mortgage (APHT) in accordance with the form which has been stipulated by the regulation of the minister of agrarian state/head of BPN number 3 of 1996 which is attended by HT givers, creditors as HT recipients and 2 witnesses, this APHT is useful for ratifying a Dependent Right which will later be used by both parties concerned in making an agreement credit or in other words as evidence that there is a collateral between the creditor and the debtor which if at any time one of the parties defaults can be used.

Constraints in implementing Electronic Mortgage Rights include the following: ${ }^{36}$

a) There are constraints from the creditor (bank).

In the Law or regulations regarding Mortgage Rights (Act No. 4 of 1996) it is stated that: "after the deed is signed, within 7 working days it must be followed up with registration at the BPN office." However, often problems occur when there are many deeds but the time frame for settlement is not sufficient, because registration of Mortgage Rights at the BPN office is not only the document that is entered but also has to attach other files, for example a power of attorney from the bank when it is not clear, it must be searched for or even replaced with a clearer one. Then there are banks that send their proxies by fax and later have to wait for the original power of attorney not in fax form.

b) There are obstacles from the debtor (client).

Apart from the technical constraints experienced by the PPAT Notary Public Office, sometimes the installation of this Mortgage is hampered by the financial burden experienced and must be paid by the debtor. ${ }^{37}$ If a debtor wants to apply for credit to a bank with collateral for immovable property, a Mortgage Rights must be automatically placed and the debtor is subject to non-tax state revenue, abbreviated as PNBP. So a debtor besides having to pay fees to the bank such as fees, administrative fees, interest and so on, the debtor must also pay notary fees for making a Notary/PPAT deed and still be burdened again with PNBP.

\footnotetext{
${ }^{35}$ Subagyo P, Joko. (2006). Metode penelitian Dalam Teori dan Praktek. Cetakan Kelima Jakarta: Rineka Cipta.

${ }^{36}$ Interview with Handojono Halimana, as Notary-PPAT City of Pekalongan on January 28, 2020

37 Interview with Handojono Halimana, as Notary-PPAT City of Pekalongan on January 28, 2020
} 
PNBP in this case is PNBP for Mortgage Rights. This is regulated in Government Regulation Number 13 of 2010 concerning Types and Rates of Non-Tax State Revenues Applicable to the National Land Agency. PNBP regarding Mortgage Rights is often considered quite burdensome to debtors because in the Government Regulation regarding PNBP Mortgage Rights it is detailed and stated nominal rates or fees for the installation of Mortgage Rights. For example, the installation of Mortgage Rights above 1 billion must pay PNBP of 2.5 million/per sector. Then for the installation of Mortgage Rights above 10 billion, the PNBP is 25 million/per sector.

c) There are Constraints from the BPN Office.

Activities related to land issues are never separated from their affairs with the land office. In the implementation of the imposition of Mortgage Rights, it must automatically have something to do with the BPN office. According to the UUHT, it is clearly stated that the granting of Mortgage Rights must be registered with the land office no later than 7 (seven) working days after the signing of the APHT. However, in reality in the field after registering, sometimes there are still things that must be taken care of and it takes time, for example, the object of the Mortgage is the result of a sale and purchase and the original land certificate has not been reversed by the owner, so it must be processed to reverse the name first. Usually the process of transferring this name can take more than 7 (seven) working days.

The presence of an electronic HT system is expected to simplify the bureaucratic process of land registration, not to be counter-productive, such as checking certificates on line, which results in two jobs (must be on line but manual is still running). The weakness of the online system is that it is prone to errors in data entry, and errors in entering the intended system, all depending on the readiness of human resources (it is important to train operators to work professionally). The main weakness is actually in the data center server, not only projects that pursue imaging and use random servers.

The roles and responsibilities of PPAT in making APHT legally are the roles and responsibilities in the implementation of obligations based on the applicable laws and regulations. ${ }^{38}$ In carrying out his professional duties, a PPAT who receives the deed has obligations before and after making the deed. The roles and responsibilities of PPAT in making PPAT in making APHT are making APHT in accordance with the provisions stipulated in the applicable laws and regulations, namely by filling in a form of deed made and issued by the National Land Agency of the Republic of Indonesia which is specifically available in full according to the instructions for filling it, filling in the blank deed in the framework of making PPAT deeds, in this case the APHT must be in accordance with the correct incident, status and data, and supported by documents in accordance with statutory regulations.

\footnotetext{
${ }^{38}$ Adjie, Habib. (2008). Hukum Notaris Indonesia, Tafsir Tematik Terhadap UndangUndang Nomor 30 Tahun 2004 Tentang Jabatan Notaris. Bandung: Refika Aditama. p. 6
} 
3.3 Efforts of the Notary/PPAT and the Land Office on electronic mortgage certificates based on the Minister of Agrarian Regulation Number 9 of 2019

The Regulation of the Minister of Agrarian Affairs Number 9 of 2019 is a continuation of the previous ATR/KBPN Ministerial Regulation, namely Permen 3/2019 concerning the use of electronic systems and Permen 7/2019 concerning changes to certificate forms, with the issuance of these candy is a rare step forward for the Ministry of Agrarian Affairs and Agency Spatial Planning National Land in making it easier for people to get services from the ministry by taking advantage of technological developments.

Article 13 paragraph (1) UUHT requires APHT to be registered at the Land Office. The registration is carried out by the Land Office. However, the UUHT does not regulate who is the applicant for the HT registration. In PP 24/1997, those who can request land registration are land owners or rights recipients. Likewise in the case of mortgage rights, the applicant for registration is the recipient of a mortgage, namely creditors. So far, registration is done manually by submitting physical evidence at the counter at the land office, with PPAT first registering the registration online on the official portal of the Ministry of ATR/BPN. . Application for registration and submission of APHT shall be carried out simultaneously by PPAT or an authorized person.

Article 3 paragraph (2) Permen No. 9/2019 which regulates that the mortgage services "can" be carried out electronically through the HT-el System. The phrase "can" implies that there are options in obtaining mortgage services, namely manually as before, or through the HT-e system. Permen 9/2019 also regulates special matters, including in Article 7, namely HT-el users are creditors, Article 9 paragraph (5) the HT provider must be the debtor himself. Thus, if the HT provider is not a debtor, he/she cannot use the HT-el service, which means that HT registration is done manually/physically. The provisions of Article 9 paragraph (5) are not prohibited from granting HT by other parties (collateral owners) who are not debtors.

The regulation also separates the prevailing customs, namely the act of applying for APHT registration from the submission of APHT by PPAT. The submission of the APHT is an obligation of the PPAT under the threat of sanctions if it is negligent. Meanwhile, the application for $\mathrm{HT}$ registration services acts as an attorney acting on behalf of $\mathrm{HT}$ recipients or creditors.

HT-e service is only an alternative and not mandatory. If after the implementation of HT-el then manual HT services are not organized or eliminated by the Land Office, then it means that the Land Office which refuses to register HT-el outside HT-el is contrary to Permen 9/2019 and UUHT. In the event that HT-el registration services outside the HT-el system are abolished, where HT-el only registers HT from the debtor's HT Giver (vide Article 9 paragraph (5), it can be interpreted that Article 9 paragraph (5) Permen 9/2019 as a form prohibition for HT that does not belong to the debtor and it is against the UUPA and UUHT. Parties who are harmed by the enactment of Article 9 paragraph (5) can file a judicial review at the Supreme Court of the Republic of Indonesia. Use of Electronic Systems on Other Land Services Based on Permen No. 3/2019 concerning electronic signatures and Permen No. 7/2019 regarding the form of SHAT, it seems 
that the Ministry of ATR/BPN is preparing to use information technology in providing land services for the community.

PPAT and the Land Office's Notary Efforts towards electronic mortgage certificates based on the Minister of Agrarian Regulation Number 9 of 2019 are that PPAT needs to apply the principle of prudence in examining HT-el certificates submitted by tappers. It is necessary for PPAT to know the characteristics and characteristics of HT-el outputs, including the general physical form, signature, stamp, impression of the original HT-el. This requires the role of the Head of the BPN Regional Office and the Head of the Land Office to provide guidance to PPAT as regulated in Article 5 paragraph 2 letter $\mathrm{c}$ Regulation of the Minister of ATR/Head of BPN RI Number 2 of 2018 concerning Guidance and Supervision of Land Deed Maker Officials.

\section{Closing}

\subsection{Conclusion}

The Notary/Ppat's Responsibilities to Electronic Mortgage Certificates Based on the Regulation of the Minister of Agrarian and Spatial Planning/Head of the National Land Agency of the Republic of Indonesia Number 9 of 2019/Juncto Number 5 of 2020, conclusions can be drawn: 1) Responsibilities of PPAT Notaries the electronic mortgage certificate based on the Regulation of the Minister of Agrarian Affairs Number 9 of 2019 is to assist the government's duties (in this case the Ministry of ATR/BPN). HT-el service is a form of service provision from the Ministry of ATR/BPN in facilitating services to the community by taking advantage of developments in information technology. The HT-el service users are the HT and ASN recipient creditors in charge of the HT service. PPAT is exempted from the obligation to represent the applicant (creditor) but PPAT is still obliged to submit the deed it has made, including APHT as quickly as possible and no later than 7 days. The absence of access to PPAT for HT-el is to restore the functions, duties and authority of PPAT as a public official who has the authority to make deeds regarding certain legal actions. 2) Obstacles to PPAT Notary in storing electronic mortgage documents include a) the existence of constraints from the Creditor (Bank), where in every credit binding process the Notary-PPAT always confirms to the parties both creditors (Bank) and Debtor (Client) to be able cooperate and behave professionally by providing direction, explanation and understanding during the implementation of Encumbrance to completion, due to errors in data entry, and errors in entering the intended system b) Constraints from the Debtor (Client). Regarding financial burdens, the Notary-PPAT provides a solution for Debtors or their clients who object to paying the mortgage installation rates whose certificates or land are more than one plot of land, c) Constraints from the BPN, which are for clients who want all the management processes such as checking, registration, roya and others related to the installation of Mortgage Rights at the BPN office can use an accelerated process even though they have to pay more than the specified administrative fee. 3 ) PPAT and Land Office Notary Efforts towards electronic mortgage certificates based on the Regulation of the Minister of Agrarian Affairs Number 9 of 2019 are that PPAT 
Notaries need to apply the principle of prudence in examining HT-el certificates submitted by tappers. It is necessary for PPAT to know the characteristics and characteristics of HT-el outputs, including the general physical form, signature, stamp, impression of the original HT-el. This requires the role of the Head of the BPN Regional Office and the Head of the Land Office to provide guidance.

\subsection{Suggestion}

Then the author also has some suggestions, namely Notary/PPAT should make readiness in procurement of electronics and technology that are qualified in HT-e registration and need to apply the principle of prudence in examining HT-e certificates submitted by tappers. Actually, ATR/BPN doesn't have to bother doing such and such surveys. Just copy and paste the AHU online system (don't be embarrassed). Apart from that, every thing there must be advantages and disadvantages of each. In this case we are asked to be wise in taking existing things, because everything must return to the professionalism and integrity of bureaucratic services itself.

\section{References}

Books:

[1] Adjie, Habib. (2008). Hukum Notaris Indonesia, Tafsir Tematik Terhadap UndangUndang Nomor 30 Tahun 2004 Tentang Jabatan Notaris. Bandung: Refika Aditama.

[2] Bahsan, M. (2007). Hukum Jaminan dan Jaminan Kredit. Jakarta: Raja Grafindo Persada.

[3] Bahsan, M. (2010). Hukum Jaminan dan Jaminan kredit Perbankan Indonesia. Jakarta: PT. Raja Grafindo Persada.

[4] Cashmere. (2012). Manajemen Perbankan. Jakarta: Raja Grafindo Persada.

[5] Habib, Adjie. (2007). Hukum Notaris Indonesia, Tafsir Tematik Terhadap Undang-Undang Nomor 30 Tahun 2004 tentang Notaris. Surabaya: Refika Aditama.

[6] Harahap, M. Yahya. (1997). Beberapa Tinjauan Tentang Permasalahan Hukum Buku Kedua. Bandung: Citra Aditya Bakti.

[7] Harsono, Boedi. (1999). Hukum Agraria Indonesia Sejarah Pembentukan Undang-Undang Pokok Agraria, Isi dan Pelaksanaannya. Cetakan ke-8. Jakarta: Djambatan.

[8] Harsono, Boedi. (2007). Hukum Agraria Indonesia, Himpunan PeraturanPeraturan HukumTanah. Jakarta: Djambat. 
[9] Hermansyah. (2005). Hukum Perbankan Nasional Indonesia. Jakarta: Prenada Media.

[10] HS, H. Salim. (2017). Perkembangan Hukum Jaminan di Indonesia. Jakarta: Raja Grafindo Persada.

[11] HS, Salim. (2005). Perkembangan Hukum Jaminan dilndonesia. Jakarta: Rajawali Pers.

[12] HS, Salim. (2007). Perkembangan Hukum Jaminan di Indonesia. Jakarta: Raja Grafindo Persada

[13] HS, Salim. (2014). Perkembangan Hukum Jaminan di Indonesia. Jakarta: PT Raja Grafindo.

[14] HS, Salim. (2015). Teknik Pembuatan Akta Satu. Jakarta: PT. Raja Grafindo Persada.

[15] Kusumaatmadja, Mochtar. (2003). Hukum, Masyarakat dan Pembinaan Hukum Nasional. Jakarta: Binacipta.

[16] Lili Rasjidi, Ira Thania Rasjidi. (2002). Pengantar Filsafat Hukum. Mandar Maju. Bandung: Thafa Merdeka.

[17] Nurita, Emma. (2012). Cyber Notary. Bandung: PT. Rafika Aditama.

[18] Patrik, Purwahid and Kashadi. (2008). Hukum Jaminan. Edisi Revisi dengan UUHT. Semarang : Fakultas Hukum (Universitas Diponegoro Semarang.

[19] R. Soegondo, Notodisoerjo. (1993). Hukum Notariat Di Idonesia Suatu Penjelasan. Jakarta: Raja Grafindo Persada.

[20] S. Suriasumantri, Jujun. (2007). Filsafat Ilmu Sebuah Pengantar Populer. Jakarta: Pusataka Sinar Harapan.

[21] Samekto, Fx Adji. (2013). Hukum Dalam Lintasan Sejarah. Semarang: Indepth Publishing.

[22] Sjahdeini, Sutan Remy. (1999). Hak Tanggungan Asas-Asas KetentuanKetentuan Pokok dan Masalah Yang Dihadapi Oleh Perbankan (Suatu Kajian Mengenai Undang-Undang Hak Tanggungan). Bandung: Alumni.

[23] Soedjendro, Kartini. (2001). Perjanjian Peralihan Hak atas Tanah yang Berpotensi Konflik. Yogyakarta: Kanisius.

[24] Soejono, Abdurrahman. (1998). Prosedur Pendaftaran Tanah Hak Milik, Hak Sewa Bangunan, Hak Guna Bangunan. Jakarta: Rineka Cipta.

[25] Subagyo P, Joko. (2006). Metode penelitian Dalam Teori dan Praktek. Cetakan Kelima Jakarta: Rineka Cipta. 
[26] Sudrajat, Sutardja. (1997). Pendaftaran Hak Tanggungan dan Penerbit Sertifikatnya, Bandung: Mandar Maju.

[27] Sutedi, Adrian. (2006). Implikasi Hak Tanggungan Terhadap Pemberian Kredit Oleh Bank dan Penyelesaian Kredit Bermasalah. Jakarta: BP Cipta Jaya.

[28] Sutedi, Adrian. (2012). Hukum Hak Tanggungan. Jakarta: Sinar Grafika.

[29] Thamrin, Husni. (2010). Pembuatan Akta Pertanahan oleh Notaris. Yogyakarta: LaksBang Pressindo.

[30] Untung, H. Budi. (2012). Visi Global Notaris. Yogyakarta: Andi.

Internet:

[1] Kedudukan dan Kepastian Hukum Hak Tanggungan Elektronik, https://notarymagazine.com/kedudukan-dan-kepastian-hukum-ht-elektronik/, accessed on 10 November 2020

[2] Mekanisme Pendaftaran Hak Tanggungan Secara Elektronik, https://www.hukumonline.com/klinik/detail/ulasan/lt5d78bcd61c63c/mekanismependaftaran-hak-tanggungan-secara-elektronik/, accessed on 10 November 2020

Regulation:

[1] The 1945 Constitution of the Republic of Indonesia;

[2] Civil Code;

[3] Act No. 30 of 2004 concerning Notary Position

[4] Act No. 4/1996 concerning Mortgage Rights to Land and Objects Related to Land

[5] Regulation of the Minister of Agrarian Affairs and Spatial Planning / Head of the National Land Agency of the Republic of Indonesia No. 9 of 2019.

Interview:

Interview with Handojono Halimana, as Notary-PPAT City of Pekalongan on January 28, 2020 